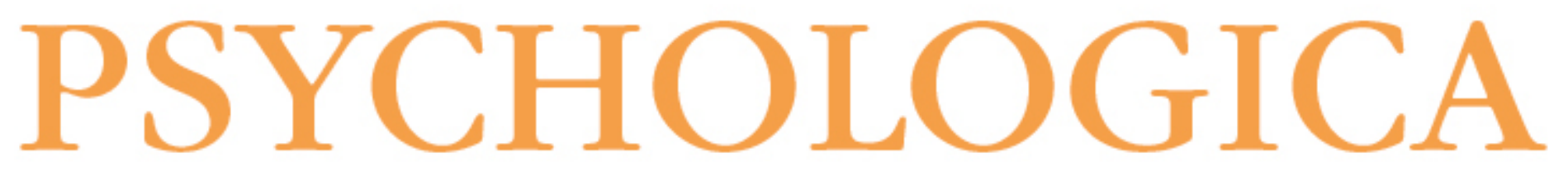

The impact of accountability on judgments of ethical decisions

Autor(es): $\quad$ Silva, Vítor H.; Simões, Eduardo

Publicado por: Imprensa da Universidade de Coimbra

URL

persistente: URI:http://hdl.handle.net/10316.2/5614

Accessed : $\quad$ 26-Apr-2023 06:19:21

A navegação consulta e descarregamento dos títulos inseridos nas Bibliotecas Digitais UC Digitalis, UC Pombalina e UC Impactum, pressupõem a aceitação plena e sem reservas dos Termos e Condições de Uso destas Bibliotecas Digitais, disponíveis em https://digitalis.uc.pt/pt-pt/termos.

Conforme exposto nos referidos Termos e Condições de Uso, o descarregamento de títulos de acesso restrito requer uma licença válida de autorização devendo o utilizador aceder ao(s) documento(s) a partir de um endereço de IP da instituição detentora da supramencionada licença.

Ao utilizador é apenas permitido o descarregamento para uso pessoal, pelo que o emprego do(s) título(s) descarregado(s) para outro fim, designadamente comercial, carece de autorização do respetivo autor ou editor da obra.

Na medida em que todas as obras da UC Digitalis se encontram protegidas pelo Código do Direito de Autor e Direitos Conexos e demais legislação aplicável, toda a cópia, parcial ou total, deste documento, nos casos em que é legalmente admitida, deverá conter ou fazer-se acompanhar por este aviso.

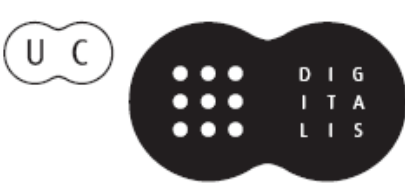




\section{NÚMERO 55}

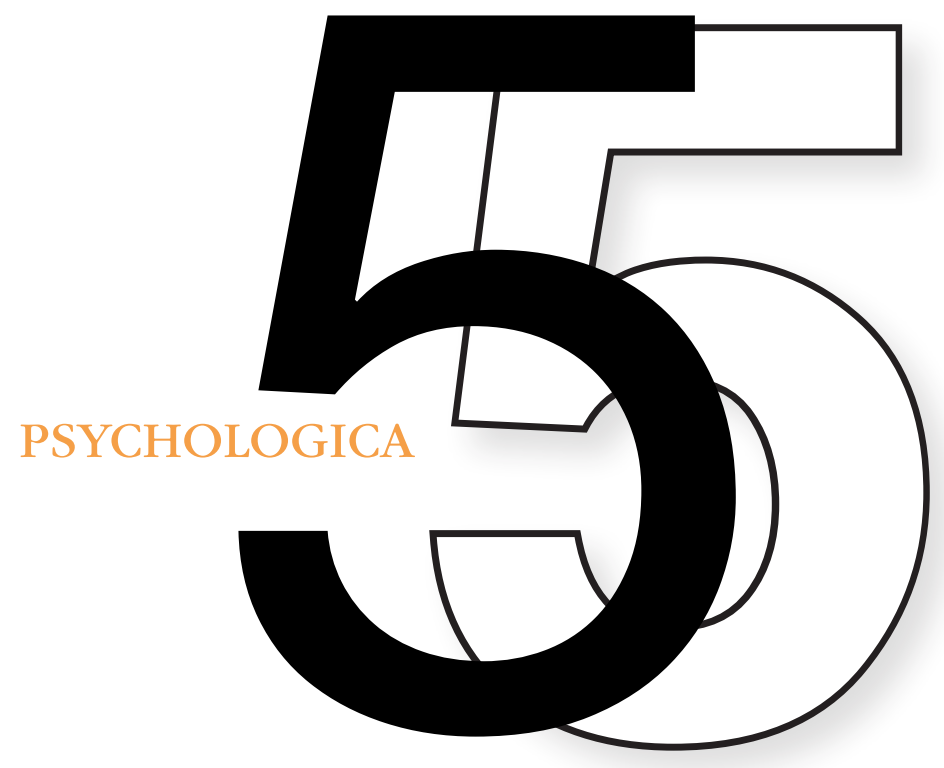

PSICOLOGIA DAS

ORGANIZAÇÕES

DO TRABALHO E DOS

RECURSOS HUMANOS 


\title{
The Impact of Accountability on Judgments of Ethical Decisions
}

\author{
Vítor H. Silva ${ }^{1}$ \& Eduardo Simões ${ }^{2}$
}

When appraising the ethicality of another person's decision, individuals tend to take the valence of the consequences as a basis for their judgment. Specifically, an ethically dubious decision tends to be more acceptable when the consequences are displayed as positive. This paper discusses the results of observation of the effect of accountability to unknown third parties on this process. Results from an experimental study ( $N=251)$ indicate that individuals under process accountability tend to be more severe in their judgment of the acceptability of other's ethically dubious decisions than the non-accountable ones and those who are under outcome accountability, but only when the decision's consequences are displayed as positive or neutral. This effect does not occur when the consequences of the decision are seen as negative. In this case, people tend to consider the decision ethically unacceptable, regardless of whether or not they're held accountable to unknown constituents. These tendencies are independent of the individual differences in the propensity to make cognitive effort in problem analysis. Results are discussed from the perspective of decision making in organizations, and their possible relevance to the establishment of mechanisms to increase the scrutiny of the ethicality of decisions.

KEY-WORDS: ethical decision-making, accountability, need for cognition

The current global economic crisis, preceded by numerous scandals at formerly renowned financial institutions, has demonstrated the failure of many legal measures unleashed in response to cases that, in the early years of the new millennium, had involved companies like Enron, Tyco, WorldCom, among others. Legal texts such as the Sarbanes-Oxley Act in the United States, or the Loi sur la Sécurité Financière in France don't seem to have been effective in the prevention of behavior ethical failings. Even the establishment of specific "ethical infrastructures" (Tenbrunsel, Smith-Crowe \& Umphress, 2003) in organizations, such as the codes of conduct, does not seem to be enough to ensure ethical integrity of organizations.

\footnotetext{
1 Department of Social and Organizational Psychology/Centre for Psychological Research and Social Intervention (CIS-IUL) - Lisbon University Institute (ISCTE) - vitor_hugo_silva@iscte.pt

2 Department of Social and Organizational Psychology - Lisbon University Institute (ISCTE)
} 
Public leaders and decision makers tend to consider ethical problems in organizations as reflecting the action of some "bad apples" that would be urgent to stop and punish. So, in this view, ethical failures are characteristics of some specific individuals or groups. Consequently, many normative efforts to ensure ethicality in organizations seem to be rooted in the belief that controlling it is to refine the requirements that prevent the emergence of such behaviors.

Until recently, in psychological research, the dominant view on individual ethical decision making portrayed the individual as a conscious decision maker, and aware of all possibilities of moral choices. Regarded as reference in the field (e.g., Jones, 1991; McDevitt, Giappone \& Tromley, 2007), the model of Rest $(1986,1994)$ built on the work of Kolhberg (Kolhberg \& Kramer, 1969; Kolhberg, 1976) on the cognitive basis of moral judgments, conceives the decision process as a succession of four phases: (1) the decision maker recognizes the moral issue, (2) develops a moral judgment, (3) puts the moral aspects of other aspects of setting up a moral intent and $(4)$ acts on this moral intent.

However, in the last two decades, accumulated evidences point to the idea that "good" people can also do "bad" things (De Cremer, 2009), i.e., most unethical behavior is out of conscious control, and may even conflict with the moral standards of the individual. This approach suggests that although people consider themselves more ethical than the average (Epley \& Dunning, 2000) their decisions on ethical issues are systematically biased by self-interest (Banaji, Bazerman \& Chugh, 2003). It follows that ethical failures are not characteristic of particular groups of individuals, and understanding their nature and causes require examining how people interpret and acknowledge situations in which these problems occur. On the other hand, unethical abuses exist in a web of social relations in which the judgment of others reinforces, discourages or ignores these behaviors. Social context factors, as the nature of the organizational reward system (Jessen, 2003; Locke, 2001) or the goal-setting process (e.g., Ordóñez, Schweitzer, Galinsky \& Bazerman, 2009), appear to enhance the individual propensity to (not) recognize ethical problems and conflicts of interest when people are faced with the need to make decisions which involve ethical dubious issues. Organizational features, e.g., the punishment or the tacit acceptation of unethical behavior, frame individual choices in working settings and indicate to individuals the informal norms regarding ethicality in the workplace (Treviño, Weaver, \& Reynolds, 2006; Tenbrunsel et al., 2003).

When individuals observe and judge the ethicality of others' decisions, how rational and accurate are they? From a rational - normative perspective, evaluating the ethical quality of someone's decision should be independent of random and external factors associated to the decision making process. But, previous research 
has shown that we are affected, in a biased way, by the decision outcome to determine the perception of "moral intensity" of the ethical issues (Jones, 1991), which, in turn, seems to assign the wrongdoer's blame and whether he or she deserves punishment (Goldberg, Lerner, \& Tetlock, 1999).

As thinking and deciding about the ethicality of decisions and behaviors of other people seems to be based on superficial information and stimulus, it may be reasonable to ask if thinking in a more deeply and logical way could lead us to more accurate inferences.

In this paper, we deal with ethical meta-decision making, i.e., we focus the way individuals make judgments about the ethical quality of others' decisions, as well as the effects of some contextual and individual factors on this process. Specifically, we are interested in exploring the effects of accountability to third parties as a possible debiasing factor in the judgment of ethicality of others' decisions, through an increase of individual's cognitive effort. On the other hand, we tested the possible moderating effect of the individual intrinsic motivation to process information in a deep and systematic way.

\section{Information processing in ethical decision-making}

\section{Dual information processing models revisited}

People do not always make decisions based on clear criteria and preferences, and don't analyze carefully the available alternatives, as advocated by the rational choice models of decision-making (Kahneman, 2003). On the contrary, in most cases, individuals use inferences which they've made on the basis of their interpretation of the world (e.g., Higgins \& Bargh, 1987). Thus, sometimes individuals seek to follow logical procedures, explicit and conscious, but on the other hand, they often adopt intuitive and automatic processes, and /or based on emotion (Stanovich \& West, 2000; Kahneman, 2003; Bazerman \& Moore, 2009). This type of cognitive functioning, which relies on the use of heuristics, i.e., decision rules of thumb or simplified strategies of information processing. Although heuristic information processing is in general adaptive, it often generates biases in judgment and puts into question the quality of decisions.

This assumption that individuals can process information by using two ways in cognitive operations (e.g., Chaiken, 1980; Chen \& Chaiken, 1999; Wilson, Lindsey \& Schooler, 2000) is the core statement of the dual processing models. For ins- 
tance, the heuristic-systematic model (Chen \& Chaiken, 1999) suggests that when people are not motivated or are limited to think about the content of a problem, they pursue a heuristic processing which reflects a less cognitive effort. On the contrary, when people are motivated to analyze a topic in a logical and systematic way and, moreover, have prior skills and information to do so, they tend to focus on content and structure of the problem. The way individuals choose to process information, systematically or through a heuristic approach, seems to be influenced by personal and contextual variables.

Individual differences may interfere with the choice of one or another way of processing the information. Specifically, individuals are more or less driven by the need for cognition (Cacioppo \& Petty, 1982), which reflects the motivational disposition to seek knowledge independently of the characteristics of the situation and information. Lower or higher levels of need for cognition seem to predispose people respectively to the use of heuristics, adopting a less systematic cognitive functioning, or to expend effort in order to understand the problem in depth and with a high degree of accuracy. Put another way, individuals with higher need for cognition tend to focus on the core aspects of the problem, while those with low need for cognition direct their attention to "peripheral elements associated with the problem" (Cacioppo \& Petty, 1982, p. 128).

The motivation to ensure accuracy in information processing, epistemic or nondirectional motivation, may not be the sole motive to promote systematic thinking. The individual may be driven by directional motivation, i.e., for other motives than accuracy, as the desire to appear to be competent, moral or successful. Given this motivational involvement, even when analyzing the information in a systematic way, the individual may focus on irrelevant information, conditioning the quality of the judgment. This is because individuals do not deal with all situations equally. They may wish to get information and knowledge on some issues to the detriment of others (Kruglanski \& Webster, 1996). Hence, these motivational orientations not only determine the amount of information analyzed but also how it is processed by the individual. As Kunda (1999) points out, "even when we are motivated to reach a particular conclusion, we are also motivated to be rational and to construct a justification (emphasis added) for our desired conclusion that would persuade a dispassionate observer" (p. 224). This means, first of all, that directional motivation does not exempt the gathering of enough information and evidence. Secondly, the social insertion of a cognitive act (social rules, relationships, etc.) formats the outcome under the form of justification before others. Thus, some social context factors may have a de-biasing effect in the way people usually analyze information when judging other's decisions on ethical issues. Accountability may be one of these factors. 


\section{Accountability}

An individual is held accountable when she/he has the expectation, implicit or explicit, that may have to justify her/ his beliefs, feelings and actions to others. Involves the need to present appropriate and satisfactory justifications for their actions, under penalty of negative consequences (Tetlock \& Levi, 1980; Tetlock, 1983; 1999). Thus, accountability is activated whenever there's an expectation that someone's behavior is under observation and evaluation by an audience, who may or may not be known (Lerner \& Tetlock, 1999).

Individuals may be asked to account for the way they made a decision (process accountability) or for the decision's outcome (outcome accountability). Decision makers who are accountable for outcomes tend to adopt self-justifying patterns of thought and a high tendency to commit themselves to past actions (Simonson \& Staw, 1992.). Differently, under process accountability, individuals tend to engage in preemptive self-criticism, leading to more unbiased evaluation of decision alternatives (Lerner \& Tetlock, 1999; Tetlock, 1992) when compared to outcome accountability condition. Moreover, individuals who are accountable for process show more consistency in the way they make judgments (Ashton, 1992) and feel encouraged to use analytic thinking modes over large amounts of information (Siegel-Jacobs \& Yates, 1996). In turn, outcome accountability is characterized by a cognitive investment in the justification of results and a constant adjustment to meet the expectations of constituents.

\section{Ethical decision-making}

Ethical decision-making can also be accomplished through two distinct pathways: through systematic, conscious, careful and detailed analysis of available information or instead it is based on a type of fast, unintentional, and unconscious cognitive functioning characterized by recurrent use of heuristics (e.g., Bargh, 1994). For this reason, decisions on ethical issues suffer often from problems of accuracy as the individual tends to be moved by the perception of what is socially accepted as ethical or unethical (Chugh, Bazerman, \& Banaji, 2005). Additionally, the more ethically complex is the matter concerned, the greater the amount of information that the decision maker has to process, enabling the influence of factors which promote the occurrence of errors in judgment.

Reflecting this tendency for considering more probable that people often use a heuristic information processing in evaluating the decisions' ethics, the influential social intuitionist model (Haidt, 2001) suggests that moral assessment is based, as a rule, in "moral intuitions", i.e., emotions and automatic responses to stimuli with 
moral relevance. The explicit moral judgments would be rationalized explanations of these emotional reactions.

Therefore, in ethical decision-making, individuals are affected by particular social motivations. Specifically, the perception that the consequences of their actions will be under the judgment of others may activate the pursuit of ethically acceptable solutions. In fact, when decision involves ethical consequences for self and others, decision maker tends to be motivated by the perception of what is socially accepted as ethical by including a self-oriented motivation in the process (Chugh et al., 2005), whereas the consequences are seen not only desirable but also morally justified (Epley \& Caruso, 2004). It is an "illusion of objectivity" (Chugh et al., 2005), due to the fact that individuals tend to perceive themselves more ethical than the others (Tenbrunsel \& Messick, 2004). On the other hand, the difficulty of imagining the consequences of a decision can lead to a biased risk perception of the decision since people tend to think of a prospective manner (Slovic, Fischhoff, \& Lichtenstein, 1982) that is, to establish the probability of a given result to happen as the result of a decision.

In short, as heuristic processing may lead to biases in common decision-making, likewise, in ethical decisions, the motivational processes may interfere with the analysis of available information, and originate unintentional biases. Therefore, many processes of individual decision making on ethical issues can be seen as a particular case of bounded rationality, re-named "bounded ethicality" (Chugh et al., 2005).

\section{Judging the ethicality of other people's decisions}

When judging the ethicality of a decision made by others, people tend to take the valence (positive, negative or neutral) of its consequences as a basis for their judgment (Gino, Moore, \& Bazerman, 2008). This seems to be a specific instance of the outcome bias (Baron \& Hershey, 1988), i.e., the tendency of individuals to consider the information on the consequences of an action as a determinant in assessing the quality of decision-making or the competence of the decision maker, if it is a judgment about a decision made by others. Additionally, (Fischhoff, 1975) describes the "prospective bias", i.e., the use of inferences about the information supposedly held by the decision maker before the decision was made. Under this biased perception, individuals are prone to use a "flat" time framing: they evaluate the quality of the decision on the basis of outcome information that was not available earlier to the decision makers (Clarkson, Emby, \& Watt, 2002). The outcome bias affects not only the judgment about the decision's quality, but also about the decision maker's competence, to the extent that he or she was supposed to have anticipated the consequences. 
When facing a decision of dubious ethics, people tend to see it as less ethically acceptable when its consequences are negative rather than positive. From a rational point of view, the judgment concerning a process of decision making requires the use of the same information as the decision maker would have available at the time of his or her decision (Bazerman \& Moore, 2009), but the assumption that the consequences are determinants for the assessment of a decision's quality is based on the adoption of a heuristic processing of the information which focus the attention on arguments that could turn the decision in "good" or "bad" and not in the previous aspects to decision making itself. So, given the inability to predict the consequences of their actions, individuals tend to underestimate how the decision-making process is conducted, assuming implicitly that the outcome determines the acceptability of a decision. In sum, individuals ultimately are judged not for a supposed intrinsic ethicality of their actions, but for the consequences of such actions, even if they have been the product of uncontrollable factors.

This tendency to focus on decision's consequences implies the attribution of responsibility to the decision maker for the effects of her action. The perception of causality and intention lead individuals to attempts to reestablish a sense of justice (Tostain \& Lebreuilly, 2008), considering acceptable to punish someone in proportion to the severity of the consequences they are responsible for, since it's supposed that it constitutes a clear indication of the degree of negligence of the decision maker (Baron \& Hershey, 1988). As an example of this kind of bias, Alicke and Davis (1989) reported that, in a study presenting a scenario in which the owner of a house shoots over a suspected intruder, participants attributed more responsibility to the owner when the intruder was presented as an innocent victim and less responsibility when the intruder was described as a dangerous criminal.

Regarding decisions on ethical issues, Haidt (2001) has shown that negative consequences cause strong moral disapproval. Recent research also suggests that the outcome bias is a socially relevant heuristic (Agrawal \& Maheswaran, 2005), implying that individuals are motivated to manage the social impact of their decision on the basis of intuition about its social acceptability. On the other hand, the need for assigning blame and punishment is dominant and automatic, providing a source of irrationality of ethical judgments. People are driven by the "belief in a just world" (Lerner, 1980) i.e., they believe that the consequences of a decision reflect the intention and the personal characteristics of the decision maker. When consequences are negative, the individual has information that the impact of the decision have damaging repercussions for others, then assumes that it is a socially unacceptable and reprehensible behavior (Mazzocco, Alicke \& Davis, 2004), judging more severely the decision and its author (Alicke \& Davis, 1989). 


\section{A study on the effects of accountability on ethical metadecision}

Recent research indicates that the promotion of more reflexive contexts in ethical decision-making may facilitate the reduction the effect of the outcome bias (Gino et al., 2008). On the other hand, as we have seen, individuals under outcome accountability are subject to similar biases to those that occur in individuals who are not accountable (Lerner \& Tetlock, 1999), but process accountability appear to have a debiasing potential and tend to foster cognitive complexity in the analysis of problems.

So, we expected that individuals under process accountability were able to think deeply and recognize the presence of conflicts between intuitive ethics, on which their ethical judgments usually rely (Haidt \& Joseph, 2004), and the need to generate decisions to safeguard their social identity to eyes of the unknown constituents to whom they are accountable. In particular, we hypothesize that:

Hypothesis 1: When judging the acceptability of an ethically questionable decision, individuals under process accountability will be less influenced by the valence of the consequences (positive, negative and neutral) than those participants who are not accountable or under outcome accountability.

However, contextual factors like accountability to others are not the sole possible debiasing influences in ethical meta-decision. As we've previously discussed, individuals may vary in regard to the propensity to analyze information in a systematic and deep way.

Considering those individual differences in intrinsic epistemic motivation, we predict that:

Hypothesis 2: The relationship between process accountability and judgment on the acceptability of a questionable ethical decision is moderated by individual level of need for cognition.

\section{Method}

\section{Participants and Procedure}

Two hundred and fifty-one students (average age is 29.9 years, $S D=10.3$, and $82.1 \%$ are female) from four universities participated voluntarily in this study.

Participants were distributed over three distinct conditions of accountability and through three different types of consequences generated by an ethical decision- 
making. Specifically, participants believed they would have to justify how they made the decision (process accountability) or believed they would have to provide justifications for the outcome of their decision (outcome accountability). In the control group, participants were not held accountable for the experimental task.

Concerning decision's consequences, and depending on the experimental condition, participants received one of three versions of a scenario adapted from Gino and colleagues (2008) describing the ethically questionable behavior of an auditor, each one with different information about the valence of the decision's consequences: positive, negative or neutral (the description of scenarios can be found in Appendix A)

Table 1. Distribution of participants by experimental conditions

\begin{tabular}{llll}
\hline \multirow{2}{*}{$\begin{array}{l}\text { Valence of decision's } \\
\text { consequences }\end{array}$} & \multicolumn{2}{l}{ Accountability } \\
\cline { 2 - 4 } Positive & No & Process & Outcome \\
\cline { 2 - 4 } $\begin{array}{l}\text { Negative } \\
\text { Neutral }\end{array}$ & $N=25$ & $N=34$ & $N=31$ \\
\cline { 2 - 4 } & $N=21$ & $N=25$ & $N=28$ \\
\hline
\end{tabular}

\section{Variables and measures}

\section{Accountability}

The experimental manipulation of accountability has been conducted through instructions in the protocol of data collection in order to lead participants to believe that they would later participate in an interview with another researcher to gather additional data about how they had made their decision (process accountability) or about the decision's justification (outcome accountability). Participants were asked to provide an e-mail address in order to be called for an interview. They were given a sheet of paper with the title "notes to the interview," where participants could take notes considered relevant to the putative interview. Participants included in the control group were only informed that they were taking part in a study about decision-making.

\section{Acceptability of ethical decision}

The observation of the degree to which participants considered the auditor's decision acceptable was operationalized through the question "To what extent is the auditor's decision acceptable?" Seven point Likert-type scale has been used ( $1=$ not acceptable and $7=$ totally acceptable). 


\section{Need for cognition}

As hypothetical moderator variable, the extent to which participants had higher or lower intrinsic motivation to engage in careful information processing was assessed using the Need for Cognition Scale (original reduced version) (Cacioppo, Petty \& Kao, 1984) translated into Portuguese by Silva \& Garcia-Marques (2006). Participants responded to 18 items (for example, "I like to have responsibility for handling a situation that requires a lot of thinking.") using a five point Likert-type scale ( $1=$ strongly disagree and $5=$ strongly agree). The highest scores indicated highest level of need for cognition ( $\alpha .80)$.

\section{Results}

Participants were asked to indicate whether or not ( $1=$ yes; $2=$ no) they were accountable to others for the decision process (outcome). All participants answered in line with the manipulation.

We used participants' ratings of ethical acceptability as dependent variable in a two-way ANOVA in which valence of decision's consequences and experimental condition and served as between-subjects factor. Results show a main effect of the valence of decision's consequences, indicating that individual ratings about ethical acceptability are affected by outcome bias $F(2,242)=22.19, p$ $<.001, \eta^{2}=.15$, even when participants are under accountability. However, there are some experimental conditions which could be less biased by the outcome decisions $F(2,242)=14.61, p<.001, \eta^{2}=.10$, showing that under specific conditions, decision context could affect how participants evaluate decision ethicality.

Taken together, the valence (positive, negative or neutral) of the decision's consequences and accountability both influence ethical acceptability of the decision, indicating the presence of an interaction effect $F(4,242)=2.62, p$ $=.03, \eta_{\mathrm{p}}^{2}=.04$. So, we undertook and analysis of this effect by conducting a posteriori comparison tests (L-matrix) in order to identify which combinations were responsible for that. 


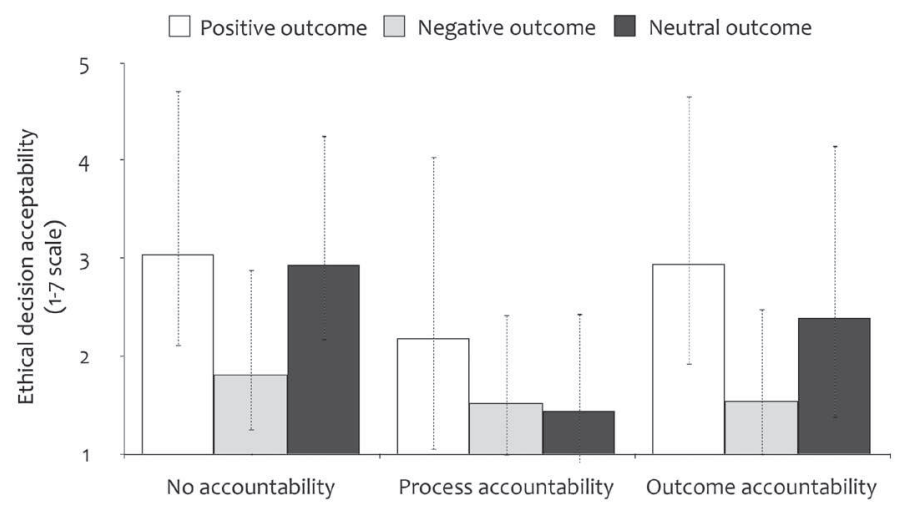

Results show that, process accountability may have a debiasing effect in the way participants analyze information about ethical decisions. In fact, face to positive consequences, participants under process accountability judge ethical decision as less acceptable $(M=2.18$; $S D=1.42)$ than participants under outcome accountability $(M=2.94 ; S D=1.29) F(1,242)=8.29, p=.004$, or than participants under no accountability condition $(M=3.04 ; S D=1.21) F(1,242)=9.54, p=.002$. In same vein, participants under process accountability, judge ethical decisions with neutral consequences as less acceptable $(M=1.44 ; S D=.71)$ than participants under outcome accountability $(M=2.39$; $S D=1.28) F(1,242)=10.65, p=.001$, or than participants under no accountability condition $(M=2.93$; $S D=.98) F(1,242)$ $=25.99, p<.001$.

However, this situation only occurs when the decision consequences are positive. In fact, there are no differences between accountability conditions if the valence of decision consequences is negative.

In order to observe the moderator role of the individual level of need for cognition we performed a two-way ANOVA (experimental conditions $x$ individual level of need for cognition) with participants' ratings of ethical acceptability as dependent variable. Results show no interaction affect from this variable, $F(16$, 223) $=.82, p=.65, \eta_{\mathrm{p}}^{2}=.05$.

\section{Discussion and Conclusions}

Consistently with the results of Gino et al. (2008), all participants tended to consider the decision with positive consequences as more acceptable than the very same decision, but with negative consequences, revealing that the valence 
of consequences influences the ethical decision process. Apparently, the outcome bias is more robust when the individual is confronted with negative consequences indicating that these ones render non acceptable the ethically dubious decision, or by salience either by recognizing that it is a socially unacceptable situation.

344 The absence of significant differences between the group of non-accountable participants and the group of participants held accountable for the decision's outcome seems to support the idea that usually in ethical decision making there is a focus on analyzing the consequences, rather than getting a global view of the problem.

Regardless of the condition of negative consequences, and supporting hypothesis 1, participants under process accountability evaluated decisions with positive or neutral consequences as less acceptable compared with the group of participants who are not accountable at all or who are under outcome accountability. This effect is independent of the individual propensity to make cognitive effort in problem analysis. Moreover, these results suggest that process accountability activates a kind of cognitive functioning based on a more thorough and systematic analysis of all elements of the decision and therefore less based on the valence of the consequences. On the contrary, our results suggests that outcome accountability is not an effective mechanism in preventing bias driven by the excessive salience of a decision's consequences, at least, in the case of ethical decision-making. However, when individuals believe that they have to account for the way they judge the ethical decisions of others (process accountability) tend to make more severe judgments, even if the consequences of the decision are displayed as positive. This effect does not occur when individuals are facing a similar decision but with negative consequences. Under this condition, both accountable and non-accountable participants tend to judge the decision as unacceptable. Put another way, process accountability seems not to interfere with the judgments about the decision when it has negative consequences. This result may be due to the high salience of negative consequences (Mazzocco et al., 2004), which allows the individual to identify how the decision specifically affects others, leading to higher culpability of whom perpetrate an ethically questionable behavior (Alicke \& Davis, 1989). Participants may anticipate that other people would never accept such behavior. Moreover, from a self-centered perspective, individuals may place themselves in the victims' shoes, which implicitly suggest that they themselves could be affected by the decision's consequences.

Taken together, the results of this study may have some relevance for ethics of organizational decision-making. In fact, they suggest that when individuals are accountable for the way they decide in situations with questionable ethical boundaries, they tend to look more closely at all the elements of the problem to the 
detriment of an exclusive focus on consequences when these are referred as positive. As accountability is a permanent feature in organizational life, it seems feasible and advantageous for preserving ethics in decision making to focus accountability on the justification of the processes rather than the outcomes of decisions.

On the other hand, regardless of the effects of accountability, and because individuals tend to emphasize negative consequences to support ethical judgments, pre-decisional analysis of decisions' consequences may foster ethicality. A possible obstacle to this precautionary analysis may be that executives tend to over-rely on intuition than on intentional deliberation due to various time pressures and demanding goals (Chugh, 2004). But, from our results, organizational decision makers should go beyond the discussion of expected positive consequences, as usual, and should take time to systematically anticipate the possible negative consequences of the various scenarios in order to increase the quality of scrutiny of the decision-making processes, especially those related to situations which may potentiate ethically dubious decisions.

\section{References}

Agrawal, N., \& Maheswaran, D. (2005). Motivated reasoning on outcome-bias effects. Journal of Consumer Research, 31, 798-805. doi:10.1086/426614

Alicke, M. D., \& Davis, T. L. (1989). The role of a posteriori victim information in judgments of blame and sanction. Journal of Experimental Social Psychology, 25, 362-377. doi:10.1016/0022-1031(89)90028-0

Ashton, R. H. (1992). Effects of justification and a mechanical aid on judgment performance. Organizational Behavior and Human Decision, 52, 292-306. doi:10.1016/07495978(92)90040-E

Banaji, M., Bazerman, M., \& Chugh, D. (2003). How (Un)Ethical Are You? Harvard Business Review, 81(12), 56-64

Bargh, J. A. (1994). The four horseman of automaticity: Awareness, efficiency, intention, and control in social cognition. In R. S. Wyer \& T. K. Srull (Eds.), Handbook of social cognition, Vol. 1, (2 $2^{\text {nd }}$ ed., pp. 1-40). Hillsdale: Lawrence Erlbaum.

Baron, J., \& Hershey, J. C. (1988). Outcome bias in decision evaluation. Journal of Personality and Social Psychology, 54, 569-579. doi:10.1037/0022-3514.54.4.569

Bazerman, M. H., \& Moore, D. (2009). Judgment in managerial decision making ( $7^{\text {th }}$ ed.). NJ: Wiley.

Cacioppo, J. T., \& Petty, R. E. (1982). The need for cognition. Journal of Personality and Social Psychology, 42(1), 116-131. doi: 10.1037/0022-3514.42.1.116

Cacioppo, J. T., Petty, R. E., \& Kao, C. F. (1984). The efficient assessment of need for cognition. Journal of Personality Assessment, 48, 306-307. doi:10.1207/s15327752jpa4803_13

Chaiken, S. (1980). Heuristic versus systematic information processing and the use of source versus message cues in persuasion. Journal of Personality and Social Psychology, 39, 752-766. doi:10.1037/0022-3514.39.5.752 
Chen, S., \& Chaiken, S. (1999). The heuristic-systematic model in its broader context. In S. Chaiken \& Y. Trope (Eds.), Dual-process theories in social and cognitive psychology (pp. 73-96). New York: Guilford.

Chugh, D. (2004). Why Milliseconds Matter: Societal and Managerial Implications of Implicit Social Cognition. Social Justice Research, 17, 203-222.

Chugh, D., Bazerman, M. H. \& Banaji, M. R. (2005). Bounded ethicality as a psychological barrier to recognizing conflicts of interest. In D. Moore, D. Cain, G. Loewenstein, \& M. H. Bazerman (Eds.), Conflicts of interest: Problems and solutions from law, medicine and public policy (pp. 74-95), New York: Cambridge University Press.

Clarkson, P. M., Emby, C., \& Watt, V. (2002). Debiasing the outcome effect: The role of instructions in an audit litigation setting. Auditing: A Journal of Practice \& Theory, 21(2), 7-20.

De Cremer, D. (2009). Being unethical or becoming unethical: An introduction. In D. De Cremer (Ed.), Psychological perspectives on ethical behavior and decision making (pp. 3-13). Charlotte: Information Age Publishing.

Epley, N., \& Caruso, E. M. (2004). Egocentric ethics. Social Justice Research, 17(2), 171-187. doi:10.1023/B:SORE.0000027408.72713.45

Epley, N., \& Dunning, D. (2000). Feeling "Holier than Thou": Are Self-Serving Assessments Produced by Errors in Self- or Social Prediction. Journal of Personality and Social Psychology, 79, 861-875. doi: 10.1037//0022-3514.79.6.861

Fischhoff, B. (1975). Hindsight ff foresight: The effect of outcome knowledge in judgment under uncertainty. Journal of Experimental Psychology, Human Perception and Performance, 1, 288-299. doi:10.1037/oog6-1523.1.3.288

Gino, F., Moore, D. A., \& Bazerman, M. H. (2008) No Harm, No Foul: The Outcome Bias in Ethical Judgments. Harvard Business School NOM Working Paper No. 08-080. Retrieved from: http://ssrn.com/abstract $=1099464$

Goldberg, J. H., Lerner, J. S., \& Tetlock, P. E. (1999). Rage and reason: The psychology of the intuitive prosecutor. European Journal of Social Psychology, 29, 781-795.

Haidt, J. (2001). The emotional dog and its rational tail: A social intuitionist approach generate to moral judgment. Psychological Review, 108, 814-384. doi:10.1037//0033-295X.108.4.814

Haidt, J., \& Joseph, C. (2004). Intuitive ethics: How innately prepared intuitions generate culturally variable virtues. Daedalus, Fall, 55-66. doi:10.1162/0011526042365555

Higgins, E. T. \& Bargh, J. A. (1987). Social cognition and social perceptions. Annual Review of Psychology, 38, 369-425. doi:10.1146/annurev.ps.38.020187.002101

Jensen, M. C. (2003). Paying people to lie: The truth about the budgeting process. European Financial Management, 9(3), 379-406. doi:10.1111/1468-036X.00226

Jones, T. M. (1991). Ethical decision making by individuals in organizations: An issue-contingent model. The Academy of Management Review, 16, 366-395.

Kahneman, D. (2003). A perspective on judgment and choice: Mapping bounded rationality. American Psychologist, 58, 697-720. doi:10.1037/0003-066X.58.9.697

Kolhberg, L. (1976). Moral stages and moralization: The cognitive-development approach. In T. Lickona (Ed.), Moral development and behavior: Theory, research and social issues (pp. 31-53). New York: Holt, Rinehart \& Wiston.

Kolhberg, L., \& Kramer, R. (1969). Continuities and discontinuities in childhood and adult moral development. Human Development, 12, 93-120.

Kruglanski, A. W., \& Webster, D. M. (1996). Motivated closing of the mind: Seizing and freezing. Psychological Review, 103, 263-283. doi:10.1037/0033-295X.103.2.263 
Kunda, Z. (1999). Social cognition - making sense of people. Cambridge, MA: MIT Press.

Lerner J., \& Tetlock, P. E. (1999). Accounting for the effects of accountability. Psychological Bulletin, 125, 255-275. doi:10.1037/0033-2909.125.2.255

Lerner, M. J. (1980). Belief in a just world: A fundamental delusion. New York: Plenum Publishing Corporation.

Locke, E. A. (2001). Motivation by goal setting. In R. T. Golembiewski (Ed.), Handbook of Organizational Behavior (pp.43-56). New York: Marcel Dekker.

Mazzocco, P. J., Alicke, M. C., \& Davis, T. L. (2004). On the robustness of outcome bias: No constraint by prior culpability. Basic and Applied Social Psychology, 26(2-3), 131-146. doi:10.1207/s15324834basp26o2\&3_3

McDevitt, R., Giapponi, C., \& Tromley, C. (2007). A model of ethical decision making: The integration of process and content. Journal of Business Ethics, 73, 219-229. doi:10.1007/ s10551-006-9202-6

Ordóñez, L., Schweitzer, M. E., Galinsky, A. D., \& Bazerman, M. H. (2009). Goals gone wild: The systematic side effects of overprescribing goal setting. Academy of Management Perspectives, 23, 6-16.

Rest, J. (1994). Background: Theory and research. In J. Rest \& D. Narváez (Eds.), Moral development in the professions: Psychology and applied ethics (pp. 1-26). NJ: Lawrence Erlbaum Associates.

Rest, J. R. (1986). Moral Development: Advances in Research and Theory. New York: Praeger.

Siegel-Jacobs, K., \& Yates, J. (1996). Effects of procedural and outcome accountability on judgment quality. Organizational Behavior and Human Decision Process, 65, 1-17. doi:10.1006/obhd.1996.0001

Silva, J. \& Garcia-Marques, T. (2006). Medindo necessidade de cognição e fé na intuição: Tradução e adaptação das duas escalas à população portuguesa. Laboratório de Psicologia, 4(1), 29-43.

Simonson, I. \& Staw, B. (1992). Deescalation strategies: A comparison of techniques for reducing commitment to losing courses of action. Journal of Applied Psychology, 77, 419-426. doi:10.1037/0021-9010.77.4.419

Stanovich, K. E., \& West, R. F. (2000). Individual differences in reasoning: Implications for the rationality debate. Behavioral \& Brain Sciences, 23(5), 645-665.

Tenbrunsel, A., \& Messick, D. (2004). Ethical fading: The role of self-deception in unethical behavior. Social Justice Research, 17, 223-235.

Tenbrunsel, AE, Smith-Crowe, K, \& Umphress, E.E. (2003). Building houses on rocks: The role of the ethical infrastructure in organizations. Social Justice Research, 16, 285-307.

Tetlock, P. E. (1983). Accountability and complexity of thought. Journal of Personality and Social Psychology, 45(1), 74-83. doi:10.1037/0022-3514.45.1.74

Tetlock, P. E. (1999). Accountability theory: Mixing properties of human agents properties of social systems. In L. L. Thompson, J. M. Levine \& D. M. Messick (Eds.), Shared cognitions in organizations: The management of knowledge (pp. 117-137). Mahwah, NJ: Lawrence Erlbaum Associates.

Tetlock, P. E., \& Levi, A. (1982). Attribution bias: On the inconclusiveness of the cognition-motivation debate. Journal of Experimental Social Psychology, 18, 68-88. doi:10.1016/0022$1031(82) 90082-8$

Tostain, M., \& Lebreuilly, J. (2008). Rational model and justification model in 'outcome bias'. European Journal of Social Psychology, 38, 272-279. doi:10.1002/ejsp.404 
Treviño, L. K., Weaver, G. R., \& Reynolds, S. J. (2006). Behavioral Ethics in Organizations: A Review. Journal of Management, 32(6), 951-990. doi:10.1177/0149206306294258

Wilson, T. D., Lindsey, S., \& Schooler, T. Y. (2000). A model of dual attitudes. Psychological Review, 107, 101-126. doi:10.1037/0033-295X.107.1.101

\section{O Impacto da Responsabilização nos Julgamentos sobre Decisões Éticas}

Quando apreciam o carácter ético de uma decisão de outrem, as pessoas tendem a tomar a natureza das consequências como base para o seu julgamento. Especificamente, uma decisão eticamente dúbia tende a ser mais aceitável quando as consequências são apresentadas como positivas. O presente estudo apresenta e discute os resultados da observação do efeito da condição de responsabilização (prestação de contas a terceiros) sobre este processo, indicando que os indivíduos responsabilizados pela forma como julgam a aceitabilidade de decisões eticamente dúbias tendem a ser mais severos nas suas apreciações quando as consequências são positivas ou neutras. Este efeito não ocorre quando as consequências da decisão são apresentadas como negativas. Neste caso, as pessoas tendem a considerar a decisão eticamente inaceitável, independentemente de estarem ou não responsabilizadas perante constituintes desconhecidos. Estas tendências são independentes das diferenças individuais na propensão para fazer esforço cognitivo na análise de problemas. Finalmente, os resultados são discutidos na perspectiva da tomada de decisão em contexto organizacional, sendo salientada a sua possível relevância para o estabelecimento de mecanismos que permitam o incremento do escrutínio da natureza ética das decisões.

PALAVRAS-CHAVE: decisão ética, responsabilização, necessidade de cognição 
Positive Consequences

An auditor is examining reports of a bank.

This bank in addition to the audit services is also an important client of other consulting services from the auditor's company.

During the process, the auditor becomes aware that some accounting practices are probably illegal. However, before reporting to the customer, she decides to study some similar cases to assess whether it really is facing an illegal situation or not.

The auditor discusses the matter with the client who, in turn, assures that there is nothing wrong with their accounting. The client also threatens to end the business relationship with this company audit if the auditor hampers the approval of accounts. Faced with this threat, the auditor agrees to pass up this situation for a year. At the end of the fiscal year, There has been no problem with bank accounts.

Negative Consequences

An auditor is examining reports of a bank.

This bank in addition to the audit services is also an important client of other consulting services from the auditor's company.

During the process, the auditor becomes aware that some accounting practices are probably illegal. However, before reporting to the customer, she decides to study some similar cases to assess whether it really is facing an illegal situation or not.

The auditor discusses the matter with the client who, in turn, assures that there is nothing wrong with their accounting. The client also threatens to end the business relationship with this company audit if the auditor hampers the approval of accounts.

Faced with this threat, the auditor agrees to pass up this situation for a year.

Six months later, it turns out that the client has committed fraud and the bank goes bankrupt.

This situation is related to the practices that the auditor has detected. As a consequence, 1,400 people lose their jobs and bank customers are unable to recover their savings.

\section{Neutral Consequences}

An auditor is examining reports of a bank.

This bank in addition to the audit services is also an important client of other consulting services from the auditor's company.

During the process, the auditor becomes aware that some accounting practices are probably illegal. However, before reporting to the customer, she decides to study some similar cases to assess whether it really is facing an illegal situation or not.

The auditor discusses the matter with the client who, in turn, assures that there is nothing wrong with their accounting. The client also threatens to end the business relationship with this company audit if the auditor hampers the approval of accounts.

Faced with this threat, the auditor agrees to pass up this situation for a year. 